\title{
ANALYSIS OF PRESIDENTIAL INAUGURAL ADDRESSES USING SEARLE'S TAXONOMY OF SPEECH ACTS
}

\author{
Paulus Widiatmoko \\ Universitas Kristen Duta Wacana Yogyakarta, Indonesia \\ E-mail: widiatmoko@staff.ukdw.ac.id
}

\begin{abstract}
APA Citation: Widiatmoko, P. (2017). Analysis of presidential inaugural addresses using Searle's taxonomy of speech acts. English Review: Journal of English Education, 5(2), $275-282$
\end{abstract}

Received: 10-04-2017

Accepted: 12-05-2017

Published: 01-06-2017

\begin{abstract}
This study analyzes the performance of Searle' speech acts in presidential inaugural addresses. Five presidential inaugural addresses taken as the samples of this study were analyzed using Searle's speech act taxonomy and different distinctive features of illocutionary acts. The findings of this study revealed the frequency and comparison of the speech act performance. Each inaugural address possessed distinctive characteristics influenced by sociopolitical, economic, and historical situation of the countries. In addition, some commonalities in relation to the performance of Searle's speech act taxonomy were also observed.
\end{abstract}

Keywords: speech acts, taxonomy, presidential inaugural address

\section{INTRODUCTION}

The study of how people speak and write about the world has been an important part of social science of language. Searle's work is a part of the study of language, especially of what can be called the philosophy of language. As it is known that the focus has been on performance of the speech acts, its investigation from the starting point of social science concerns with explaining social behavior. Acting by speaking or acting by other means have important aspects in common. In the words of John Searl: "a theory of language is part of a theory of action, simply because speaking is a rule-governed form of behavior" (Searle, 1969, p. 17).

Keifer and Bierwisch (1980) state that the theory of speech acts starts with the assumption that the minimal unit of human communication is not sentence or other expression, but rather the performance of certain kinds of acts, such as making statements, asking questions, giving orders, describing, explaining, apologizing, thinking, congratulating, and some other language functions. Accordingly, Searle (1969) states that speech act theory is concerned with the use of language to do things and it provides a universal characterization between 'uttering' and 'doing'. Searle's taxonomy of speech acts is said to be the improvement of Austin classifications of verdictives, exercitives, commisives, expositives, and behabitives. Therefore, Searle (1979) comes up with five categories of what he calls illocutionary acts, namely:

1. Assertives. Searle puts it: "The point or purpose of the members of the assertive class is to commit the speaker to something's being the case" (Searle 1979, p. 12). Assertives can be found true or false. They are speech acts because the speaker wants the hearer to believe that the speaker believes what he says about the world, and thus the speaker performs a speech act.

Examples are stating, complaining, and claiming. 
2. Directives, which are attempted by the speaker to get the hearer to do something. They can be modest, such as ask or strong such as order.

3. Commissives. The point of these speech acts is to commit the speaker to some future course of action. Examples are promising and offering.

4. Expressives. They express the speaker's psychological attitude towards a state of affairs that the illocution presupposes. Examples are thanking, congratulating, and apologizing.

5. Declaratives: when successfully performed these speech acts brings about the correspondence between the propositional content and reality. The saying is the doing, like 'You are fired' or 'I resign'. Such utterances often include 'hereby', to emphasize this effect.

The above conceptions of differentiating speech acts serve as the framework of this study.

On the other hand, inaugural address in this paper is seen as a communicative event involving the new president to deliver his/her speech to the whole nation and the world. The term inaugural refers to "marking of a beginning" (http://www.merriam-webster.com). A presidential inaugural address cannot be detached from its political nature. Harrison and Tony (2003) claim that politics is primarily about the acquisition and maintenance of power. It is further stated that power is inherent in the relationship between individuals, groups, the state and a wide range of what are known as 'actors' in international politics. In other words, the actors of this event are the president as the one conveying the speech, the people of the country and the whole world as the audience. Baumeister in Miller and Stiles (1986) claims that the two central selfpresentational, among others, concerns of pleasing the audience and constructing a public self. Thus, speeches are seen as a means to convey their relative power or status, and their intimacy, closeness, and solidarity. Another scholar, Bourdieu as cited in Kvasny and Truex (2001), proposes that slogans, commentaries, commitments, and promises are often used by politicians to form a labor of representation by which they attempt to construct and impose a particular view of the world while at the same time they attempt to mobilize support of those upon whom their power ultimately depends.

The content delivered can be interpreted as containing a very crucial point for the new elected president to begin his/her leadership. Specifically, it marks an ending of the previous president's term and the transfer of power from one president to the next. Regarding to this context, a presidential inaugural address then might be categorized as a political speech in which the agents seek to form and transform their vision of the world and thereby the world itself. Words become actions and the symbolic character of power is at stake (Bourdieu in Kvasny \& Truex, 2001).

Taking the above concept of presidential inaugural address to the framework of philosophy of language, therefore this study is designed to answer the following questions:

1. What speech acts performed in the presidential inaugural addresses?

2. What commonalities and differences identified in (relation to) the application of speech acts in the inaugural addresses?

\section{METHOD}

As stated previously, this study analyzed performance of speech acts of the corpus data from the presidential inaugural addresses using Searle's taxonomy. Five inaugural addresses were chosen based on the availability of the script and possibly the streaming audio or video of the inaugural addresses in the internet as not every country publishes them. Certainly, other considerations such as different features 
comprising sociopolitical contexts, and availability of resources for analyzing the context were also taken into account. The five presidents are the president of Country A (abbreviated as GWB), Country B (GMA), Country C (SBY), Country D (NM), and Country E (CSB).

The performance of their speech acts were identified and classified using Searle's taxonomy of the speech acts. However, some utterances were not easily classified. Therefore, as it has been described earlier concerning the importance of other factors and context in the interpretation of speech act performance, examinations of experiential, relational and expressive values of the words, terms or expressions used by the presidents in their inaugural address were conducted where necessary. The necessity depends on some extent with the sufficiency of clues and context that contribute and underlie the interpretation.

Taken from critical discourse analysis (Norman, 1989), by examining at experiential values, the analysis attempts to show how 'the text producer's experience of the natural or social world' and is shown in a text. A person's views of the world can be identified by assessing formal features with experiential value. Relational values may identify the perceived social relationship between the producer of the text and its recipient. The third dimension, expressive value, provides an insight into 'the producer's evaluation (in the widest sense) of the bit of the reality it relates to.' Linguistically, those clues partly might be drawn from the usage of certain terms, words, or expressions that make up the general schemes or contrasted ideas or ideology in the discourse.

Each occurrence of the speech act performance was identified and a descriptive analysis was then applied to identify the most frequently performed speech act for each inaugural address. Finally, the findings were compared to draw commonalities and differences in relation to the speech acts and context contributing to the performance.

\section{RESULTS AND DISCUSSION}

Discussion of the findings in the subsequent sections would reveal the frequency of the speech acts performance and relate them with the context of each country. Commonalities and differences shown by the inaugural address were then could be analyzed.

Table 1. Speech Acts of GMA Inaugural Address

\begin{tabular}{ccc}
\hline Illocutionary acts & $\mathbf{N}$ & $\mathbf{\%}$ \\
\hline Assertive & 26 & 23.85 \\
\hline Directive & 35 & 32.11 \\
\hline Commisive & 45 & 41.28 \\
\hline Expressive & 3 & 2.75 \\
\hline Declarative & 0 & 0.00 \\
\hline Total & 109 &
\end{tabular}

Table 1 portrays the total number of speech acts performed by president GMA in her inaugural address. From the findings, it can be inferred that the most frequently performed speech act was commissive which is slightly above $40 \%$. It is identified that GMA performed 45 commissive speech acts ranging from providing job opportunities to resolving past political events at EDSA I, II, and III. Concerning to directive speech acts, GMA mainly encouraged and asked components of the nation to work together, to unify, and to dismantle obstacles for the development of the country. Furthermore, GMA also asked the citizen to pay taxes and invite investors 
to conduct their business. In relation to assertive speech act, GMA performed slightly above $23 \%$ of showing her commitment to the truth of the expressed proposition covering various topics.

Table 2. Speech Acts of GWB Inaugural Address

\begin{tabular}{ccc}
\hline Illocutionary acts & $\mathbf{N}$ & $\mathbf{\%}$ \\
\hline Assertive & 96 & 68.09 \\
\hline Directive & 26 & 18.44 \\
\hline Commisive & 18 & 12.77 \\
\hline Expressive & 1 & 0.71 \\
\hline Declarative & 0 & 0.00 \\
\hline Total & 141 & \\
\hline
\end{tabular}

Table 2 exemplifies the percentages of speech acts as performed by President GWB. As it can be seen, the president, to some degree, committed himself to the truth of his proposition in almost $69 \%$ of the total speech acts performed. Moreover, less than fifteen percent of the speech acts deal with committing himself and the government to future actions. Small percentages were identified in the performance of expressive speech acts.

Table 3. Speech Act of SBY Inaugural Address

\begin{tabular}{ccc}
\hline Illocutionary acts & $\mathbf{N}$ & $\mathbf{\%}$ \\
\hline Assertive & 50 & 46.30 \\
\hline Directive & 20 & 18.52 \\
\hline Commisive & 26 & 24.07 \\
\hline Expressive & 12 & 11.11 \\
\hline Declarative & 0 & 0.00 \\
\hline Total & 108 &
\end{tabular}

Table 3 exemplifies types of speech acts performed by president SBY. As can be inferred from the table, SBY performed almost half of the total speech acts as statements that can be measured in terms of true and false. In this type of speech act, SBY exemplified the success of general election, the hard working general election commission, the national principles, the country current democracy, and other issues. Furthermore, above twenty percent of his speech acts deal with his commitment for future action dealing with national issues and problems. However, in some of this speech acts, instead of stating himself for doing the action, he used the term 'my administration' which refers to the government. As commonly can be seen on the other inaugural address, the SBY also performs directive speech acts mainly containing encouragement to work together in maintaining unity and achieving the national goals. Furthermore, the percentage of expressive speech acts are performed by this president is almost equal to the ones performed by another president (NM).

Table 4. Speech Act of NM Inaugural Address

\begin{tabular}{ccc}
\hline Illocutionary acts & $\mathbf{N}$ & $\mathbf{\%}$ \\
\hline Assertive & 22 & 50.00 \\
\hline Directive & 10 & 22.73 \\
\hline
\end{tabular}




\begin{tabular}{ccc}
\hline Commisive & 7 & 15.91 \\
\hline Expressive & 5 & 11.36 \\
\hline Declarative & 0 & 0.00 \\
\hline Total & 44 & \\
\hline
\end{tabular}

The numbers of speech acts performed by president NM are not as many as the other because of the length of the inaugural address. As portrayed in table 4, half of the speech acts performed belong to the assertive type. In this speech act, NM conveyed his proposition and beliefs on
South African situation related to the history and the country's future hope. Then, slightly above than $22 \%$ of the speech acts are directives and slightly under $16 \%$ belong to commissives. In contrast, more than $10 \%$ of the total speech acts performed relate to his expressions of psychological state.

Table 5. Speech act performance of CSB inaugural address

\begin{tabular}{ccc}
\hline Illocutionary acts & $\mathbf{N}$ & $\mathbf{\%}$ \\
\hline Assertive & 119 & 74.84 \\
\hline Directive & 21 & 13.21 \\
\hline Commisive & 14 & 8.81 \\
\hline Expressive & 5 & 3.14 \\
\hline Declarative & 0 & 0.00 \\
\hline Total & 159 &
\end{tabular}

President CSB performed almost 75\% on assertive type of speech acts. He mainly delivered the history, development, and future of Taiwan as a new independent country. As it is described in the table, the gap between the assertive speech act and the other ones were very big.

Table 6. Comparative percentage of the five presidents' speech act performance

\begin{tabular}{cccccc}
\hline Illocutionary acts & GMA & GWB & SBY & NM & CSB \\
\hline Assertive & 23.85 & 68.09 & 46.30 & 50.00 & 74.84 \\
\hline Directive & 32.11 & 18.44 & 18.52 & 22.73 & 13.21 \\
\hline Commisive & 41.28 & 12.77 & 24.07 & 15.91 & 8.81 \\
\hline Expressive & 2.75 & 0.71 & 11.11 & 11.36 & 3.14 \\
\hline Declarative & 0.00 & 0.00 & 0.00 & 0.00 & 0.00 \\
\hline
\end{tabular}

Based on the table above, it is observed that none of the presidents performed declarative speech act. Similarities are also identified concerning the performance of assertive speech acts for four of the presidents; GWB, SBY, NM, and CSB. The other speech acts are found out varied in the percentage of their performance.

In his inaugural address, GWB exemplified and announced to the world that his country really concerns to fight for liberty and freedom. In conveying the idealism, GWB at the early part of the speech stated his proposition that what he intended to struggle had been started by their predecessors. Then, it was also observed that he mentioned certain key phrases repeatedly, over and over again, centering on the God-given mandate of the country to intervene anywhere in the world to advance the cause of "freedom." In the 20-minutes speech, the president uttered the words "free" or "freedom" 34 times, and the 
word "liberty" 12 times. As can be inferred from the finding of this study, the use of those terms, as contrasted with the term tyranny, obviously signifies the major schemes of the inaugural address in which most of the assertive speech act deal with their idealism and rhetoric of free nation and liberty.

Another interesting finding is related to GWB performance of the other Searle's speech acts. It was observed that other speech acts were put under the framework of his idealism of creating the world free from oppression and tyranny. After series of assertive speech acts on that idealism, Bush clearly emphasized that the country would struggle for liberty and freedom for the people in other countries. Concerning this commissive speech act, among others he stated, "all who live in tyranny and hopelessness can know: the country will not ignore your oppression, or excuse your oppressors." The idealism of freedom was also directed to its citizens in the form of commissive speech acts that they would extend this vision by reforming great institutions to serve the needs of their time. The subsequent performance of commissive speech acts specified this promise more by giving highest standard to schools, building ownership society and widening home and business, retirement of saving, and health insurance. Furthermore, his performance of directive speech acts could inferred in the context of the above idealism as he put, "I ask the youngest citizens to believe the evidence of your eyes... make the choices to serve in a cause larger than your wants, larger than yourself..." Putting himself to the fulfillment of propositions for the country, GWB finally stated, “...we will give our fellows the citizens greater freedom from want and fear, make our society more prosperous, just, and equal."

Unlike GWB, different schemes were identified in GMA and SBY inaugural addresses. In her speech, in which on majority consists of commissive speech act, GMA after expressing her gratitude immediately conveyed her promises to people of the country. The commissive speech acts performed by GMA were observed as the ones in which the achievement are observable and could be measured. Some of her promises among other deal with providing more job opportunities, providing loans for entrepreneurs, expanding agriculture lands, and other benefits. Traced back to the country in 2001, one of the prominent newspaper in the country stated that there are five fundamental problems faced by this country, namely poverty, a non-performing economy a debased education, law and order (lack of absence) and graft and corruption (Benigno \& Benigno, 2001). In other words, it seems obvious why those agendas were put into priorities and raised as the major issues in GMA inaugural address.

Similar to GMA, SBY also performed a lot of commissive speech acts, although the percentage was not that much. However, different agendas obviously underlie this fifth of the country president's inaugural address. It seems that SBY attempted to accomplish reconciliation for various groups and communities in the country. SBY right at the beginning related his inaugural event with the general election and his expressive speech acts for the government as they had successfully held the general election. Then, it was followed by commissive speech act to preserve brotherhood with the president. Partly, the performance of these speech acts could be traced back to the atmosphere of competition during the general election after the country's second president era. At the 1999's general election, there were around 48 parties participated (used to be 3 big parties) and it was acknowledged as the first democratic general election in the country (The Jakarta Post, 2001). The next general election in 2004 was also markedly the country's great achievement for democracy learning since was the first direct general election. The election is conducted by choosing not from the political parties but 
directly the individuals to be seated in certain political institutions for the president. Furthermore, the fact that there are numbers of groups entitling different tribes, political parties, and religions urge the necessities to be accommodated and collaborated.

Aside from what has been stated earlier, this intention can also be seen from his speech acts of directives that in almost all of these illocutionary acts he appears to emphasize togetherness and collaborative works by means of pronoun $u s$, we, or the ones involving himself and other components of the nation. Some examples of these would be, "it is the time for us to walk together, we have passed our moment of competition, now it is time for unity, we must overcome this problem together, and other similar tones. Even, at the other part of his address he stated, "With the mandate I received from you, I am determined to be become, not only the president of the Country $\mathrm{C}$, but also the President of all of the people, all of the country people."

As has been stated in the finding of this study, president NM performed speech acts of assertive in fifty percents of his total speech acts. Conveying his concepts of liberty and being the owner of their own land, the speech acts cannot be detached from his political struggle against the racial discrimination practiced in his country. NM spent 27 years in prison on convictions for crimes that included sabotage committed when he struggled against apartheid (Yadav, 2007).

The concept of freedom is observed in both inaugural address delivered by GWB and NM. However, different from GWB's concept, the proposition of freedom in NM inaugural address can be inferred to build patriotism, feeling of togetherness, and gratitude for being freed from racism and apartheid. Thirty four occurrences of pronominal we and the ones referring to it (us, our) signify the feeling of being one destiny experiencing hard time in the past. Furthermore, his performance of speech acts mostly can be inferred back to their past history. At the end of the speech, it is clearly observed that, through directive speech acts, NM invited the collaborative participation of South African to work together, develop their nation as the ideal one based on their past experiences.

Sharing some similar features as Country D (NM), Country E had been struggled for its independence from China. On March 2000 presidential race, voters elected pro-independence candidate CSB of the Democratic Progressive Party, ending more than 50 years of Nationalist rule (Chu, 2008). Therefore, most of the assertive speech acts performed in the inaugural speech reflected historical and current situation of Taiwan as well as the future expectation of the country.

Aside from what has been presented, some points are worth to note related to other commonalities of Searle's speech act performance. First, to some degree it was observed that speech acts were performed by all of the presidents to affirm national principles, linking their history to their present situation, reconstituting people and groups, and presenting national policy of administration. Second, the series of speech act performance appeared to be arranged to show coherence of the idea presented. For instance, assertive speech acts on national principles and history were commonly performed prior to directive or commissive ones to ascertain their strength.

\section{CONCLUSION}

An inaugural address as a starting point for the elected president to lead the country and run the government certainly marks an important event as it represents the president's vision on many crucial issues, conveys the government agendas, and moreover builds his/her establishment to the whole country and the world. Reactions, criticism, and comments toward what the content of the speech show its significance 
towards socioeconomic and political situation of the country.

Observing the status of the speaker and the listeners in the event, then the language used in the inaugural address serves not only to announce the existence of the new president, but also to perform various illocutionary acts. Searle's taxonomy of speech acts seem to be able to provide analysis of what the president mean and trying to say. The contexts, historical and current conditions, indeed contribute in providing foundation towards the analysis. Therefore, combining some features of other analysis such as Critical Discourse Analysis (CDA) in the framework of speech act study appears to give more comprehensive examination of various interrelated aspects in the discourse. Further investigation employing CDA would likely contribute to the richness of discourse analysis study in this field.

\section{REFERENCES}

Benigno, G., \& Benigno, P. (2001). Monetary policy rules and the exchange rate. CEPR Discussion Paper no 2087.
Chu, Y. H. (2008). Taiwan in 2007: The waiting game. Asian Survey, 48(1), 124-132.

Harrison, \& Tony. (2003). Understanding political ideas and movement. New York: Manchester University press.

Kvasny, L., \& Truex, D. (2001). Defining away the digital divide: A content analysis of institutional influences on popular representations of technology. In Realigning research and practice in information systems development (399414). US: Springer.

Miller, N. L., \& Stiles, W. B. (1986). Verbal familiarity in American presidential nomination acceptance speeches and inaugural addresses (1920-1981). Social Psychology Quarterly, 72-81.

Norman, F. (1989). Language and power. New York: Longman.

Searle, J. R. (1969). Speech acts: An essay in the philosophy of language. Cambridge: Cambridge University Press.

Searle. (1979). Expression and meaning. Cambridge: Cambridge University Press.

Yadav, A. K. (2007). Nelson Mandela and the process of reconciliation in South Africa. India Quarterly, 63(4), 49-84. 